УДК 342.951:351.74

DOI https://doi.org/10.32837/pyuv.v0i2(27).183

С.В. Медведенко

аспірант

Одеського державного університету внутрішніх справ

\title{
ПОНЯТТЯ ТА ФОРМИ ГРОМАДСЬКОГО КОНТРОЛЮ ЗА ДІЯЛЬНІСТЮ НАЦІОНАЛЬНОЇ ПОЛІЦІї УКРАЇНИ
}

Нині правоохоронна діяльність в Україні перебуває на стадії реформування, при цьому набуває актуальності питання покращення системи контролю за діяльністю органів охорони правопорядку з боку громадськості в усіх сферах діяльності: від надання послуг населенню до протидії правопорушенням. Ефективне виконання поліцейської діяльності, спрямованої на вирішення суспільних потреб, не можливе без підтримки й допомоги суспільства.

Здійснюючи контроль, громада вступає у відносини 3 органами влади, порядок діяльності яких чітко регламентований чинним законодавством. Контроль за діяльністю поліції у всіх демократичних державах є невід'ємною рисою громадського життя. Мова йде саме про зовнішній контроль, який сприймається чи не головною умовою, яка гарантує дотримання конституційних засад, прав і свобод громадян, законність під час здійснення поліцейської діяльності [1, с. 194].

Контроль є одним з інструментальних чинників демократичного державотворення [2, с. 74], а громадський контроль водночас виступає дієвим засобом стримування свавілля посадових осіб різних органів виконавчої влади [1, с. 194].

Питанням теоретико-правових засад і реалізації контролю, у тому числі й громадського, за діяльністю правоохоронних органів приділяється значна увага. У цьому аспекті хотілося б виділити наукові праці таких учених, як О.Ф. Андрійко, М.М. Бринчука, І.П. Голосніченка, Є.В. Додіна, А.В. Денисової, С.Ф. Денисюка, А.М. Долгополова, Є.Ю. Захарова, І.Д. Казанчука, А.М. Клочко, В.К. Колпакова, О.М. Музичука, Т.В. Наливайка, О.В. Поклада, С.Г. Стеценка, Ю.С. Шемшученка, Х.П. Ярмакі та ін. Поняття та зміст громадського контролю були досліджені, однак проблеми визначення сутності громадського контролю за діяльністю Національної поліції України потребують подальшого наукового опрацювання.

Мета статті - на основі аналізу нормативно-правових актів України, праць вітчизняних і закордонних учених, практики взаємодії поліції з громадськістю визначити зміст і форми громадського контролю за діяльністю органів Національної поліції України.

Дієвий громадський контроль є не тільки важливою формою реалізації демократії в країні, а й способом залучення населення до управління державними справами в різних сферах суспільного життя. Він розглядається як інструмент громадського оцінювання ступеня виконання органами поліції їхніх соціальних завдань [3, с. 135 ]

Для досягнення мети статті необхідно визначитися 3 понятійним апаратом. Так, С.Г. Стеценко визначає, що контроль - це організаційно-правовий спосіб забезпечення законності й дисципліни, який характеризується спостереженням і перевіркою правомірності діяльності об'єкта контролю та фактичної відповідності тих чи інших фактичних дій вимогам чинного законодавства 3 можливістю втручання в оперативно-господарську та виробничу діяльність для усунення виявлених недоліків [4].

У своєму дослідженні В.Я. Малиновський вказує на контроль як процес забезпечення досягнення організацією своєї мети, що складається з установлення критеріїв, визначення фактично досягнутих результатів і запровадження корективів, якщо досягнуті результати суттєво відрізняються від установлених критеріїв [5].

В адміністративному аспекті під контролем науковці, як правило, розуміють одну з найважливіших функцій «суспільного спостереження», яка дає змогу порівняти фактичний стан тієї чи іншої галузі з вимогами, що висунуті перед нею, виявити недоліки та помилки в роботі державного органу й запобігати їм [6, с. 98].

Як правило, в науковій літературі поняття «громадський (соціальний) контроль» розглядається з позиції державного управління як гарантія, спосіб забезпечення дисципліни та законності в діяльності органів виконавчої влади, принцип, умова ефективної діяльності державного органу тощо [7, с. 44].

Дослідники питань громадського контролю вказують на природу громадського контролю, яка походить від відносин влади і громади. Оскільки розвиток суспільства відбувається за умов єдності та боротьби протилежностей між соціумом та державою, між прагненням до необмеженої свободи та необхідністю обмежень в ім'я організації суспільного життя, своє головне завдання громадська еліта бачить у приборканні автократичної експансії держави, а державна еліта - у приборканні охлократичних тенденцій соціуму [8, с. 337]. 
В енциклопедії державного управління надано визначення громадського контролю як форми участі громадськості в управлінні з метою підвищення ефективності діяльності органів публічної влади, підприємств, установ і організацій, що надають соціальні послуги [9, с. 113].

Громадський контроль - один із видів соціального контролю, який здійснюється об'єднаннями громадян та самими громадянами, що $€$ важливою формою реалізації демократії і способом залучення населення до управління суспільством та державою, як вказано в Юридичній енциклопедії за редакцією О.Ф. Андрійко [10, с. 234].

На думку Т.В. Наливайко, громадський контроль - це організаційно-правова форма об'єднання громадян на добровільних засадах задля задоволення та захисту їхніх власних та громадських законних правових, соціальних, економічних, творчих, вікових, національно-культурних та інших спільних інтересів [11, с. 3]. У своєму дослідженні В.Г. Гаращук згадує контроль із боку різних громадських формувань - профспілок, трудових колективів, партій, рухів, фондів та інших утворень та контроль із боку громадян [12, с. 169].

O.В. Поклад, аналізуючи поняття громадського контролю, вказує, що це діяльність громадян чи їх об'єднань щодо контролю за виконанням органами державної влади або їх посадовими особами положень законодавчих актів, належного виконання ними своїх повноважень та дотримання прав і свобод людини [13].

На думку Є.Ю. Захарова, громадський контроль - публічна перевірка громадянським суспільством діяльності держави на відповідність проголошеним нею цілям, коригування цієї діяльності і самих цілей, підпорядкування політики держави, діяльності її органів і посадових осіб інтересам суспільства, а також нагляд громадянського суспільства за діяльністю державних органів та органів місцевого самоврядування, спрямованою на захист і забезпечення прав і законних інтересів людини та фундаментальних свобод, на повагу до них [14].

О.Ю. Полтораков визначає громадський контроль як систему відносин громадянського суспільства з державою, яка грунтується на підзвітності органів державної виконавчої влади органам державної законодавчої влади (парламентський контроль) недержавним структурам («третьому сектору» та засобам масової інформації) [15].

Аналізуючи наведені визначення громадського контролю, робимо висновок, що громадський контроль - це цілеспрямована діяльність громадськості щодо нагляду за виконанням органами влади наданих їм повноважень, дотримання законності, дисципліни, прав і свобод людини.

Варто підкреслити, що проблемою цього виду контролю є те, що діяльність громадськості не можна назвати контролем у повному розумінні цього слова, тому що у процесі здійснення громадського контролю відсутня така ознака контролю, як право втручатися в оперативну діяльність та право притягати підконтрольного суб'єкта до юридичної відповідальності.

Однією з новел законодавства України щодо діяльності органів Національної поліції є закріплення в законі окремого розділу «Громадський контроль поліції, в якому передбачені форми громадського контролю за діяльністю Національної поліції України.

Так, Законом України «Про Національну поліцію» [16] встановлюються форми громадського контролю, до яких зараховано такі: 1) звіт про поліцейську діяльність; 2) прийняття резолюції недовіри керівникам органів поліції; 3) взаємодія між керівниками територіальних органів поліції та представниками органів місцевого самоврядування; 4) спільні проекти із громадськістю; 5) залучення громадськості до розгляду скарг на дії чи бездіяльність поліцейських [16].

Зміст ст. 86 Закону України «Про Національну поліцію» визначає, що з метою інформування громадськості про діяльність поліції керівник відповідного підрозділу поліції та керівники територіальних органів поліції раз на рік готують та поширюють на офіційних веб-порталах органів поліції звіт про діяльність служб та підрозділів поліції[16].

Ми погоджуємося з думкою А.М. Клочко, яка вважає, що в цьому разі про здійснення контрольних функцій не йдеться зовсім, закріплення в Законі України «Про Національну поліцію» норми стосовно можливості отримання інформації від органів та підрозділів поліції не $є$ важливим. Нагальною є потреба в законодавчій регламентації самого процесу отримання інформаційних звітів від керівництва поліцейських підрозділів. Формальні відповіді на запити та номінальні звіти, які мають місце в сучасному житті, жодним чином не відповідають вимогам здійснення громадського контролю за діяльністю поліції [1, с. 197].

Зважаючи на те, що головним критерієм оцінювання ефективності діяльності органів і підрозділів поліції є рівень довіри населення до поліції, пріоритетного значення набуває поширення в інформаційному просторі сегмента об’єктивних відомостей про її діяльність.

Ст. 87 Закону України «Про Національну поліцію» встановлюе можливість прийняття резолюції недовіри керівникам органів поліції [16]. Така діяльність передбачає змогу представницьких органів територіальних громад, а саме органів місцевого самоврядування, висловлювати незадоволення діяльністю поліції відповідного територіального підрозділу.

Якщо населення не задоволено роботою поліції, зокрема станом організації співпраці поліції 3 населенням, якістю і своєчасністю виконання 
працівниками поліції покладених на них обов’ язків, у тому числі щодо сприяння вирішенню проблем, які стоять перед територіальними громадами, на засіданнях відповідних обласних, районних і міських рад може розглядатися питання про недостатньо ефективну роботу територіального органу поліції. Після чого за результатами оцінювання його діяльності на території відповідної області (району) місцеві ради своїм рішенням приймають резолюцію недовіри керівнику відповідного органу Національної поліції, що $є$ підставою для звільнення його з обійманої посади [17, с. 311-314].

3 огляду на можливий механізм прийняття резолюції недовіри керівнику поліції, діяльність якого, на думку громадськості, не відповідає основним завданням діяльності поліції, варто наголосити, що контрольна діяльність громадськості буде здійснюватися через їх представників в органах місцевого самоврядування, а безпосередній вплив на діяльність поліції відсутній. Такий вплив можливий лише у судовому порядку стосовно працівників поліції, які порушують права, свободи та інтереси держави, фізичних та юридичних осіб.

Відповідно до ст. 90 Закону України «Про Національну поліцію», залучення представників громадськості до спільного розгляду скарг на дії чи бездіяльність поліцейських та до перевірки інформації про належне виконання покладених на них обов’язків відповідає однієї з ознак громадського контролю - змозі безпосередньо впливати на діяльність поліції [16].

Не менш важливе значення має така форма громадського контролю, як взяття участі представників громадськості в атестуванні поліцейських, яке здійснюється 3 метою оцінки їхніх ділових, професійних, особистих якостей, освітнього та кваліфікаційного рівнів, фізичної підготовки на підставі глибокого і всебічного вивчення, визначення відповідності посадам, а також перспектив їхньої службової кар'єри.

Відповідно до Наказу МВС України від 17.11.2015 p. № 1465 [18], до складу атестаційних комісій можуть бути включені, за згодою, народні депутати України, представники громадських, правозахисних організацій, представники проектів міжнародної технічної допомоги, громадськості та засобів масової інформації за пропозиціями, які були отримані після розміщення відповідних оголошень на офіційних сайтах MBC чи органів поліції, та за наявності їхньої згоди.

Зазначимо, що місцеве самоврядування на підставі положень Конституції України, Закону України «Про місцеве самоврядування» здійснюється територіальною громадою в порядку, встановленому законом, як безпосередньо, так і через представницькі органи [19].
Керівниками територіальних органів поліції проводяться відкриті зустрічі із представниками органів місцевого самоврядування на рівнях областей, районів, міст і сіл із метою налагодження ефективної співпраці між поліцією та органами місцевого самоврядування й населенням.

На таких зустрічах працівники поліції інформують населення про стан правопорядку та рівень злочинності й розглядають фактори, що сприяють їх появі. У ст. 6 Закону України «Про інформацію» передбачено, що, в тому числі, на поліцію покладено обов'язок інформувати громадськість і засоби масової інформації про свою діяльність, а також створювати можливість для вільного доступу до статистичних даних, інших баз даних та інформаційних ресурсів [20].

Підготовка та виконання поліцією спільних проектів, програм і заходів з іншими державними органами (насамперед місцевими державними адміністраціями) та громадськістю здійснюється для задоволення потреб населення й покращення ефективності виконання поліцією покладених на неї завдань. 3 метою формування позитивного іміджу поліції проводиться вивчення громадської думки.

Головна мета громадського контролю - усунення та попередження причин, які породжують цю невідповідність, забезпечення додержання об'єктами контролю писаних та неписаних норм [21, с. 47].

Ми підтримуємо думку В.Л. Федоренко щодо того, що громадський контроль становить собою інструмент громадської оцінки ступеня виконання органами влади та іншими підконтрольними об'єктами їхніх соціальних завдань. Тобто характерні відмінності громадського контролю від будь-якого іншого виду контролю лежать у суб'єктно-об'єктній сфері і полягають у тому, що, по-перше, громадський контроль здійснюється саме громадськістю (організованою та неорганізованою), i, по-друге, що в процесі здійснення громадського контролю контролюється виконання саме соціальних завдань, безпосередньо пов'язаних із захистом і реалізацією прав і свобод громадян, задоволенням та узгодженням соціальних потреб та інтересів населення [8].

Підсумовуючи викладене, можна зробити висновок, що громадський контроль за діяльністю Національної поліції - це цілеспрямована діяльність громадськості (громадян України, іноземців, громадських організацій, представників установ i підприємств) щодо виконання органами Національної поліції України повноважень, дотримання ними законності, дисципліни, захисту прав і свобод людини, інтересів суспільства та держави.

Мета громадського контролю за діяльністю органів Національної поліції України спрямована на недопущення протиправних дій із боку підкон- 
трольних суб’єктів, попередження можливих правопорушень та усунення причин, що їм сприяють.

Форми громадського контролю можна поділити на: правові, що здійснюються на підставі нормативних актів (залучання до проведення атестації працівників поліції громадськість), та неправові (організаційні), що полягають у проведенні спільних нарад працівників поліції з представниками громадськості; здійснюються індивідуальними суб'єктами контролю (окремими громадянами) та груповими суб'єктами (громадськими об'єднаннями).

Ми погоджуємося з думкою 3.С. Гладуна, що суб’єктами громадського контролю є, по-перше, громадяни i, по-друге, об’єднання громадян (політичні партії, професійні спілки, молодіжні й інші громадські організації). Їх контрольні повноваження, як правило, не мають юридично-владного змісту, тому рішенням громадських організацій за результатами перевірок притаманний рекомендаційний характер [22].

Для практичної реалізації громадського контролю, на нашу думку, необхідно створити відповідні сайти, на які може надходити інформація (відео, аудіо, електронні документи), в тому числі й анонімна, від представників громадськості щодо протизаконної діяльності працівників поліції.

Громадський контроль сприяє утвердженню громадянського суспільства, в якому забезпечуються права та свободи людини і громадянина, а об’єктом контролю є органи влади.

\section{Jimepamypa}

1. Клочко А.М., Собина В.О. Громадський контроль за діяльністю поліції в Україні. Вісник НУЦЗУ. Серія: Державне управління. 2017. Вип. 1 (6). С. 194-201.

2. Іжа М., Радченко О. Громадський контроль в системі публічного управління як ефективний інструмент експертизи державно-управлінських рішень. Публічне управління: теорія та практика. 2012. Т. 4. C. 74-79.

3. Казанчук І.Д. Поняття й форми громадського контролю за діяльністю правоохоронних органів у сфері охорони навколишнього природного середовища в інтеграційних умовах. Порівняльно-аналітичне пра 6o. 2017. № 3. С. 134-138.

4. Стеценко С.Г. Адміністративне право України : навч. посібник. Вид. 2-ге перер. і доп. Київ : Атіка, 2009. 640 c.

5. Малиновський В.Я. Державне управління. Київ : Атіка, 2003. 576 с.

6. Лученко Д.В. Місце контролю в системі адміністративно-правових форм діяльності. Проблели законності. 2006. Вип. 82. С. 97-103.

7. Гаращук В.М. Контроль та нагляд у державному управлінні Харків : Фоліо, 2002. 176 с.

8. Федоренко В.Л. Інститути громадянського суспільства та інститут громадських організацій в Україні: теоретико-методологічні та нормопроектні аспекти. Бюлетень Міністерства юстииї України. 2009. № 4-5. URL: www.minjust.gov.ua

9. Енциклопедія державного управління: у 8 т. Нац. акад. держ. упр. при Президентові України / наук.-ред. колегія: Ю.В. Ковбасюк (голова) та ін. Київ : НАДУ, 2011. Т. 1.748 с.

10. Андрійко О.Ф. Громадський контроль : юрид. енцикл. : в 6 т. / редкол. : Ю.С. Шемшученко (голова редкол.) та ін. Київ : Укр. енцикл., 2001. Т. 3. 790 с.

11. Наливайко Т.В. Громадський контроль в Україні як інститут громадянського суспільства : теоретико-правовий аспект : автореф. дис. ... канд. юрид. наук : 12.00 .01 Львів, 2010. 18 с.

12. Гаращук B.M. Теоретико-правові проблеми контролю та нагляду у державному управлінні : дис. ... д-ра юрид. наук : 12.00.07 / Національна академія імені Ярослава Мудрого. Харків, 2003. 272 с.

13. Поклад О.В. Поняття та зміст громадського контролю за діяльністю поліції в Україні. Право і суспільство. 2016. № 2. С. 139-145.

14. Захаров Є.Ю. Громадський контроль та права людини. Громадська мережа «Опора» URL: http://opora.lviv.ua. $/ \mathrm{p}=529$.

15. Полтораков О.Ю. Громадський контроль над «силовими» структурами в Україні: проблеми та перспективи. Національний інститут проблем міжнародної безпеки. Публікації. URL: http://www.niisp.org. ua/defau 38.php.

16. Про національну поліцію : Закон України від 02.07.2015 p. № 580-VIII. Дата оновлення / База даних «Законодавство України»/ Верховна Рада України. URL: http://zakon.rada.gov.ua/laws/show/580-19.

Закон України «Про Національну поліцію» : наук.-практ. комент. / MBC України, Харків. нац. ун-т внутр. справ ; за заг. ред. д-ра юрид. наук, доц. В.В. Сокуренка ; [О.І. Безпалова, К.Ю. Мельник, О.О. Юхно та ін. ; передм. В.В. Сокуренка]. Харків : ХНУВС, 2016. $408 \mathrm{c}$.

17. Про затвердження Інструкції про порядок проведення атестування поліцейських МВС України : Наказ МВС України від 11.07.2015 р. № 1465 / База даних «Законодавство України» / Верховна Рада України. URL: http://zakon5.rada.gov.ua/laws/show/z1445-15/ paran15\#n15

18. Про місцеве самоврядування в Україні : Закон України від 21.05.1997 р. № 280/97-ВР. Відомості Верховної Ради України. 1997. № 24. Ст. 170.

19. Про інформацію : Закон України від 02.10.1992 p. № 2657-XIIII. Відомості Верховної Ради України. 1992. № 48. Ст. 650.

20. Денисюк С.Ф. Громадський контроль як гарантія законності у адміністративні діяльності правоохоронних органів в Україні : монографія. Харків : Золота миля, 2010. $368 \mathrm{c.}$

21. Гладун 3.С. Державна політика охорони здоров'я в Україні (адміністративно-правові проблеми формування і реалізації) : монографія. Тернопіль : Економічна думка, 2005. 460 с.

\section{Анотація}

Медведенко С. В. Поняття та форми громадського контролю за діяльністю Національної поліції України. - Стаття.

У статті досліджуються поняття і форми громадського контролю за діяльністю Національної поліції України. Звернуто увагу, що контроль є одним 3 iнструментальних чинників демократичного державотворення та невід'ємною рисою громадського життя. Проаналізовано праці науковців щодо поняття та ознак громадського контролю. На підставі аналізу визначень поняття «громадський контроль» надано власне визначення громадського контролю як цілеспрямованої діяльності громадськості щодо виконання органами влади наданих їм повноважень, дотримання закон- 
ності, дисципліни, прав і свобод людини. Переглянуто новели українського законодавства щодо форм громадського контролю за діяльністю органів Національної поліції України, визначено їх позитивні та негативні аспекти. Зауважено, що громадський контроль має відмінність від інших видів контролю, під час якого громадськість не має повноважень втручатися в оперативну діяльність поліції та притягувати працівників поліції до відповідальності. 3'ясовано мету громадського контролю за діяльністю працівників поліції, спрямовану на недопущення протиправних дій із боку підконтрольних суб'єктів, попередження можливих правопорушень та усунення причин, що їм сприяють. Надано власне визначення громадського контролю за діяльністю Національної поліції України. Запропоновано створення спеціальних веб-сайтів для надання різного типу інформації щодо протизаконної діяльності працівників поліції.

Ключові слова: контроль, громадськість, національна поліція, діяльність поліції, громадський контроль.

\section{Summary}

Medvedenko S. $V$. Concepts and forms of public control over the activities of the National Police of Ukraine. - Article.

The article focuses on concepts and forms of public control over the activities of the National Police of
Ukraine. It is emphasized that control is one of the instrumental factors of democratic state formation and an integral feature of public life. The scientists' works on concept and features of public control are analyzed. Based on the analysis of the definitions of concept of "public control", a definition of public control is given, as it is a purposeful public activity of fulfilling the powers conferred on them by authorities, due course of law, discipline, human rights and freedoms. The revisions of the Ukrainian legislation were reviewed, regarding the forms of public control over the activity of the bodies of the National Police of Ukraine, and their positive and negative aspects were determined. It is noted that public control is different from other types of control, during which the public does not have the authority to interfere with the police operative activities and to hold police officers accountable. The purpose of public control over the activities of police officers has been clarified, aimed at preventing unlawful acts by controlled entities, preventing possible offenses and eliminating the reasons that would prevent them. It is provided author's own definition of public control over the activities of the National Police of Ukraine. It is suggested that special websites be created to provide various types of information on illegal activities of police officers.

Key words: control, public, national police, police activity, public control. 